\title{
Investor Limited Information Processing Capacity: Industry Level Analysis
}

\author{
Winston Sutandar, Angel, Trixie Josunarto, John Iwan Kusno, Adrian Teja \\ Universitas Prasetiya Mulya \\ email: adrian.teja@pmbs.ac.id
}

\begin{abstract}
Investor has cognitive limitation in the form of limited information-processing capacity relative to the amount of information available to them. This limitation force investors to optimize their valuable resources by focusing only to a specific set of information based on their unique preference. Since different industry have different information complexities, different industries will have different investor segment in terms of investor number, investor sophistication, and investor speed to gather and to comprehend information from other industry. We investigate the prevalence of investor's limited information-processing capacity in Indonesian stock market using autoregressive model. We used monthly data from 31 December 1999 to 30 September 2015 to identify whether there are industries that consistently lead other industries. We find only mining industry return, with small market capitalization only $3.3 \%$ relative to total Jakarta Composite Index market capitalization, which consistently leads Jakarta Composite Index return for one to two months.
\end{abstract}

Keywords: Behavioral finance, lead-lag relations, limited information-processing capacity, market anomaly, investor segment.

\begin{abstract}
Abstrak
Investor memiliki keterbatasan kognitif dalam bentuk kapasitas pemrosesan informasi yang terbatas relatif terhadap jumlah informasi yang tersedia bagi mereka. Keterbatasan ini memaksa investor untuk mengoptimalkan sumber daya mereka yang berharga dengan memfokuskan hanya pada serangkaian informasi spesifik berdasarkan preferensi unik mereka. Karena industri yang berbeda memiliki kompleksitas informasi yang berbeda, industri yang berbeda akan memiliki segmen investor yang berbeda dalam hal jumlah investor, kecanggihan investor, dan kecepatan investor untuk mengumpulkan dan memahami informasi dari industri lain. Kami menyelidiki prevalensi kapasitas pemrosesan informasi investor yang terbatas di pasar saham Indonesia menggunakan model autoregresif. Kami menggunakan data bulanan dari 31 Desember 1999 hingga 30 September 2015 untuk mengidentifikasi apakah ada industri yang secara konsisten memimpin industri lain. Kami hanya menemukan pengembalian industri pertambangan, dengan kapitalisasi pasar kecil hanya 3,3\% relatif terhadap total kapitalisasi pasar Indeks Komposit Jakarta, yang secara konsisten menyebabkan pengembalian Indeks Komposit Jakarta selama satu hingga dua bulan.
\end{abstract}

Kata kunci: Behavioral finance, lead-lag relations, limited information-processing capacity, market anomaly, investor segment.

\section{INTRODUCTION}

Research in behavioral finance is growing in importance vis-à-vis standard finance literature (Statman, 2014; Oprean and Tanasescu, 2014). The main differences between behavioral finance and 
standard finance are that the behavioral finance assumes investors as normal people who normally make mistakes because of cognitive errors and emotional biases as opposed to rational people who do not make mistakes in standard finance. Behavioral finance believes normal people are not irrational, but gravitating from 'normal smart' to 'normal stupid'. This definition is more strongly reflect actual people than standard finance that do not reflect actual people.

Behavioral finance distinguishes people's error into cognitive error and emotional bias. According to Pompian (2016), cognitive errors are basic statistical errors, information-processing, or memory errors that cause the decision to deviate from the rational decisions of traditional finance. Examples of cognitive errors are conservatism bias, confirmation bias, representativeness bias, illusion of control bias, hindsight bias, anchoring and adjustment bias, mental accounting bias, framing bias, and availability bias. Cognitive errors is easier to control than emotional bias. Higher quality information will eliminate cognitive errors. Emotional biases arise spontaneously as a result of people attitudes and feelings that can cause the decision to deviate from the rational decisions of traditional finance. Examples of emotional bias are loss-aversion bias, overconfidence bias, self-control bias, status quo bias, endowment bias, and regret-aversion bias. Emotional biases is harder to control than cognitive error. Higher quality information cannot eliminate emotional biases. However, several biases have both cognitive and emotional aspect that makes control becoming more difficult.

The main similarity between behavioral finance and standard finance in predicting market return is that both theories believe that investors cannot consistently earn abnormal return. But, the reason of inability to consistently earn abnormal return is different. Standard finances argue that the market price is 'right' hence there is no possibility to earn abnormal return. There are no investor that willing to buy overprice stock and no investor that willing to sell underprice stock. Behavioral finance believes even though the market price is 'wrong', investor do not know that the price is 'wrong'. Hence, investor may not react to 'wrong' price. Lack of reaction makes 'wrong' price will not be corrected in a predictable way. Lack of predictability means investor cannot earn abnormal return consistently.

While both argue that investors cannot consistently earn abnormal return, it is very difficult to prove which theory is more prevalent in the market. Standard finance acknowledges three categories of anomaly. The first calendar anomalies are January Effect and Turn-of-the-Month Effect. The second fundamental anomalies are Low Price to Book, Low Price to Earning, and High Dividend Yield. And the third anomalies are technical anomalies, such as Moving Averages, Momentum Effect, and Lead-Lag Relation. The anomaly happens because of inappropriate or flawed methodology caused by the fact that most of the time the anomaly disappears after being documented and analyzed in the academic literatures. The anomaly is nonexistent if the analysis is using a different time period, and the abnormal return exists because we use the wrong model or wrong benchmark. 
However, research findings and new explanations on market anomalies keep on growing, which provide a good foundation for alternative explanation (Kleidon 1986). One alternative explanation comes from behavioral finance that do not treat the research findings on market anomaly as anomaly but as a normal market being driven by normal people with their normal limitations.

In this paper, we are interested in explaining market anomalies from technical anomaly categories, specifically lead-lag relations. There is a growing number of research findings and explanations of lead-lag relation dominated by standard finance literatures (see Chiao, Hung, and Lee, 2004; Pokswale and Theobald, 2004; Qiao, Li, and Wong, 2008; Judge and Reancharoen, 2014; Arjoon, Bougheas, and Milner, 2016; Drakos, 2016). To our knowledge, the alternative explanation within behavioral finance strand, specifically limited information-processing capacity, is not yet being performed.

In this paper, we are focusing only on lead relations in order to test investor segment capabilities to understand economics faster than other investor segment. Based on this argument, our paper research question is "Is there industries that consistently lead stock market". The novelty of this paper is behavioral theory tested, i.e. limited information-processing capacity. Previously, popular behavioral theory tested in Indonesia stock market mostly regarding market anomaly that not consistently exist in Indonesia stock market.

There are several implications of limited information-processing capacity, such as the fact that different industries have different segments of investors. Different investor have different level of sophistication, different speed to gather and comprehend information from other industries. This differences enable certain industries to consistently lead other industries. We investigate the prevalence of investor's limited information-processing capacity in Indonesian stock market using a monthly return data during the time period from 31 December 1999 to 31 December 2015. Our research using Indonesian data also contributes to theories and empirical evidence on lead-lag relations in emerging markets.

\section{LITERATURE REVIEW AND HYPOTHESIS DEVELOPMENT}

Standard finance does not differentiate the level of information complexities, while in realities, different information has different level of complexities. Merton (1987) argues that information processing is costly because investors need cognitive efforts to comprehend information. More complex information is more difficult to comprehend and more costly to cognitive effort. For example, information related to consumer goods industries is relatively more predictable than information related to high technology industries. Since information is costly, not all investors are willing to spend their valuable resources to gather and comprehend complex information from sources that not directly relevant to their investment focus. 
As the information gets more complex, investors may need more time to comprehend the information, and the slower the information is reflected in the stock price. Peng (2005) reports Japanese investors need one week to process the worst earthquake information to comprehend the implications on Japan economic growth; US investors need more than five months to comprehend the business implication of new cancer drug from Entremed. Hong, Torous, and Valkanov (2007) argue that investors do not only have limited information-processing capacity but investors also have different speed of information-processing capacity. They find certain industries may move faster than the market or lead the market, certain industries may move in line with the market or coincide the market, and certain industry will move the market slower or lag the market.

Investors have limited information-processing capacity relative to the amount of information universe, with different complexities, that is available to them. Investors will choose to optimize their valuable resources, i.e. cognitive, to a specific set of information with specific level of complexities. Peng and Xiong (2006) find that investors choose to analyze simpler sector-wide information rather than firm-specific information because sector-wide information is more simple.

Finance literatures acknowledge that investors are divided into two categories; i.e. individual investor and institutional investor. The main differences between individual investor and institutional investor are institutional investor believed to have lower limitation in information-processing capacity because institutional investors mostly work as a team and devote significantly a great amount of time and resources to analyze information, rather than individual investors who work alone with limited time and resources to analyze information. The theoretical prediction of characteristic differences is that institutional investors do not have specific industry preference because they relatively have unconstrained cognitive resources, Whereas, individual investors have to choose a specific industry based on their preferences to optimize their limited cognitive resources.

Empirical findings confirm that limited information-processing capacity creates investor segments as well as limited attention. The concept of investor segment is discussed by MacGruder Barnewall's Two Way model in 1987 that divides investor into active investor and passive investor and Thomas E. Bailard, David L. Biehl, and Ronald W. Kaiser's Five Way model in 1986 that classified investors based on personality traits, i.e. level of confidence and method of action. And more recently, Sahi and Arora (2012) conducted a study on Indian retail investors and divided investors into four distinct investor segments, i.e. novice learner, competent confirmer, cautious anticipator and efficient planner.

Each investor segment has specific investment preferences and they hardly shift their attention to other investment types. Bodnaruk and Ostberg (2009) find evidence in the impact of investor recognition on return premium. Companies that have lower investor recognition yield larger returns than companies that have higher investor recognition. Hacibedel (2014) find that analysts start to turn their attention to new stock inclusion into an important benchmark, such as MSCI. Hacibedel finds 
that stock inclusion shows permanent positive abnormal return while exclusion does not result in permanent negative abnormal return.

In summary, limited information-processing capacity creates investor segments that have limited attention to information outside their specific preferences. Different industries have different investor segments in terms of number, sophistication, and speed to gather and comprehend information from other industries. There are possibilities that each investor segment fail to comprehend the implication of the same information to different industries. Then, we hypothesize that there are industries that are able to consistently lead the market.

\section{DATA AND METHODOLOGY}

\section{Data and Summary Statistics}

Macroeconomic data, industry data and Indonesian stock index data were obtained from Bloomberg. The classification of industry is based on Jakarta Stock Classification Index (JASICA). JASICA classifies industries in Indonesia into nine industries, which are JAKAGRI (Agriculture), JAKBIND (Basic Industry and Chemicals), JAKCONS (Consumer Goods), JAKFIN (Finance), JAKINFR (Infrastructure, Utilities and Transportation), JAKMIND (Miscellaneous), JAKMINE (Mining), JAKPROP (Property Real Estate and Building Construction), JAKTRAD (Trade Services and Investment). The earliest complete data concerning industries, such as the number of listed companies and market capitalization, are provided by Bloomberg in 2002. However, each industry's index is already available before the number of listed companies and market capitalization of each industry. We are using monthly industrial returns from 31 December 1999 to 30 September 2015. We exclude one stock that is not included in any industry classification. See Table 1 for industries statistics.

The table presents the summary of each industry index characteristic. Column two to four present the number of listed companies in each industry index at end of 2002, end of 2005, end of 2010, and at end of 2015. Column five to eight present the market capitalization of each industry index at the end of 2002, end of 2005, end of 2010, and at end of 2015. Column nine to twelve present our calculation for the weight of each of the industry index relative to JCI at end of 2002, end of 2005, end of 2010, and on 30 September 2015.

From Table 1, we can see that Indonesian stock market already experiences positive development from market capitalization value, number of companies listed, and level of diversification. Indonesian market capitalization values grow from Rp. 267.01 trillion at the end of year 2002 to 4,443.12 on 30 September 2015. Numbers of listed companies grow from 336 companies in the end of 2002 to 518 on 30 September 2015. And, the level of diversification is improved as it can be seen from the declining market capitalization weight contributions of three largest market capitalization industries, such as JAKFIN, JAKCONS, and JAKINFR from $70.6 \%$ in the end of 2002 to $57.8 \%$ by 30 September 2015, and growing market capitalization weight contributions of three lowest market capitalization 
industries, such as JAKMINE, JAKAGRI, and JAKPROP from 5.5\% in end of the year 2002 to $20.3 \%$ at 30 September 2015. Three middle market capitalization weight contributions, such as JAKMIND, JAKTRAD, and JAKBIND also declined from $23.9 \%$ at the end of 2002 to $21.9 \%$ on 30 September 2015.

Table 1. Summary of Industries Index Characteristics

\begin{tabular}{|c|c|c|c|c|c|c|c|c|c|c|c|c|}
\hline \multirow{2}{*}{ Industry } & \multicolumn{4}{|c|}{ Number of Listed Companies } & \multicolumn{4}{|c|}{ Market Capitalization } & \multicolumn{4}{|c|}{ \% weight to Jakarta Composite Index } \\
\hline & 2002 & 2005 & 2010 & 2015 & 2002 & 2005 & 2010 & 2015 & 2002 & 2005 & 2010 & 2015 \\
\hline JAKFIN & 57 & 64 & 69 & 86 & 70.87 & 213.47 & 811.92 & $1,243.50$ & $26.5 \%$ & $28.6 \%$ & $26.0 \%$ & $25.5 \%$ \\
\hline JAKCONS & 42 & 36 & 33 & 36 & 66.24 & 96.49 & 356.15 & 686.61 & $24.8 \%$ & $12.9 \%$ & $11.4 \%$ & $23.1 \%$ \\
\hline JAKINFR & 13 & 16 & 33 & 53 & 51.41 & 191.36 & 462.96 & 637.66 & $19.3 \%$ & $25.6 \%$ & $14.8 \%$ & $13.1 \%$ \\
\hline JAKMIND & 50 & 51 & 42 & 42 & 24.15 & 58.42 & 265.21 & 303.91 & $9.0 \%$ & $7.8 \%$ & $8.5 \%$ & $6.2 \%$ \\
\hline JAKTRAD & 65 & 64 & 93 & 115 & 21.13 & 45.26 & 241.86 & 379.76 & $7.9 \%$ & $6.1 \%$ & $7.8 \%$ & $12.8 \%$ \\
\hline JAKBIND & 59 & 55 & 59 & 64 & 18.66 & 53.76 & 246.75 & 288.04 & $7.0 \%$ & $7.2 \%$ & $7.9 \%$ & $5.9 \%$ \\
\hline JAKMINE & 9 & 10 & 28 & 43 & 8.49 & 60.00 & 509.50 & 161.50 & $3.2 \%$ & $8.0 \%$ & $16.3 \%$ & $3.3 \%$ \\
\hline JAKAGRI & 9 & 9 & 15 & 21 & 3.03 & 12.44 & 105.23 & 118.56 & $1.1 \%$ & $1.7 \%$ & $3.4 \%$ & $2.4 \%$ \\
\hline JAKPROP & 32 & 32 & 47 & 58 & 3.03 & 16.37 & 120.66 & 623.57 & $1.1 \%$ & $2.2 \%$ & $3.9 \%$ & $7.8 \%$ \\
\hline Total & 336 & 337 & 419 & 518 & 267.01 & 747.58 & $3,120.24$ & $4,443.12$ & $100 \%$ & $100 \%$ & $100 \%$ & $100 \%$ \\
\hline
\end{tabular}

\section{Methodology}

The Standard finance research measures time adjustment using a short time period. For example, event studies for Initial Public Offering (IPO) measure abnormal return using a one-day and five-day period. Based on this research methods, we define behavioral finance research method using a longer time period. We use one month prior, two months prior, and three months prior to prove that price adjustment due to new information does not happen.

We analyze industry lead-lag relations with autoregressive model using several steps. First, we use equation 1 to examine whether industries return is able to predict returns of Jakarta Composite Index (JCI) using three time periods, such as one-month, two-month prior, and before three-month prior periods. Second, we use equation 2 to examine whether industries return are able to predict returns of Jakarta Composite Index (JCI), also using three time periods, i.e. from one-month, twomonths, and three-month prior periods, after we added three control variables such as inflation rate, change in deposits rate, and change in exchange rate. Inflation rate is obtained from change in CPI. Deposit rate is obtained from the average of 1 month deposit rate of Tier 4 Bank in Indonesia (Bank BCA, Bank BNI, Bank BRI, Bank Mandiri). Exchange rate is stated as Indonesian Rupiah value relative to the US Dollar value.

Our models to explore the ability of industry returns to lead the market are as follows:

$R M_{t}=\alpha_{i}+\lambda_{i, R_{i, t-n}}+\varepsilon_{i, t}$ 
$R M_{t}=\alpha_{i}+\lambda_{i, R_{i, t-n}}+A_{i} Z_{t-n}+\varepsilon_{i, t}$

Where $\mathrm{RM}_{t}$ is the return of the market in month $t, R_{i, t-n}$ is the return of industry portfolio is prior one month, two month, and three month. There are nine industries on JASICA (Jakarta Stock Classification Index). $\mathrm{Z}_{\mathrm{t}-\mathrm{n}}$ is a vector of additional market predictors from inflation rate, change in deposits rate, and change in exchange rate for equal period.

Second, we are also interested in investigating whether Subprime Mortgage Crisis has a major influence on industries return capabilities to predict JCI return. We define that Subprime Mortgage Crisis starts in 2007 and ends in 2009. We used equation 1 and equation 2 above using data that exclude industries return data from 31 December 2006 to 31 December 2009.

\section{RESULTS AND DISCUSSION}

\section{Industries Ability to Predict the Market Without and With Control Variables}

The regression results of all industries with JCI return as shown in Table 2 below, shows that only JAKMINE return is able to predict the JCI return one month and two months prior and is significant at alpha $1 \%$ and $10 \%$ respectively. As we add our regression model with control variable in Table 3 i.e. inflation rate, change in deposits rate, and change in exchange rate, we find only the JAKMINE return that is able to predict the JCI return one month prior and is significant at alpha $1 \%$. JAKMINE coefficients in both regression models have positive values which means that if the current JAKMINE return is positive, then the Jakarta Composite Return will also be positive in the next month.

This table presents the results from industries' return ability to predict JCI returns in t-1, t-2, and $\mathrm{t}-3$. The numbers besides the industry's name represent the t-stat for the before industry return to predict the JCI return at month $\mathrm{t}$. The number under the t-stat is the p-value for the before industry return ability to predict the JCI return. CONST represents the alpha from the model. The numbers beside it represent the $t$-value and the numbers under the $t$-value are the $p$-value. In addition, each $\mathrm{R}^{2}$ and adjusted $\mathrm{R}^{2}$ of the model is displayed below the p-value of the CONST. The sample period is 31 December 1999 - 30 September 2015.

Table 2 presents the results from industries return and control variable ability to predict JCI returns in $\mathrm{t}-1, \mathrm{t}-2$, and $\mathrm{t}-3$. The numbers besides the industry name represent the $\mathrm{t}$-stat for the previous industry return to predict the JCI return at month t. The number under the t-stat is the p-value for the previous industry return ability to predict the JCI return. CONST represents the alpha from the model. The numbers beside it represent the t-value and the numbers under the t-value are the p-value. In addition, each $\mathrm{R}^{2}$ and adjusted $\mathrm{R}^{2}$ of the model is displayed below the p-value of the CONST. The sample period is 31 December 1999 - 30 September 2015. 
Table 2. Regression Results of The Industry Returns' Ability to Predict JCI Returns

\begin{tabular}{|c|c|c|c|}
\hline \multirow[b]{2}{*}{ Industry } & \multicolumn{3}{|c|}{ Dependent Variable: RM (ID) } \\
\hline & Month (t-1) & Month (t-2) & Month (t-3) \\
\hline \multirow[t]{2}{*}{ JAKAGRI } & 0.028 & 0.014 & $(0.009)$ \\
\hline & 0.478 & 0.232 & $(0.146)$ \\
\hline \multirow[t]{2}{*}{ JAKBIND } & 0.100 & 0.110 & $(0.059)$ \\
\hline & 0.964 & 1.015 & $(0.553)$ \\
\hline \multirow[t]{2}{*}{ JAKCONS } & $(0.119)$ & 0.094 & 0.084 \\
\hline & $(1.124)$ & 0.843 & 0.761 \\
\hline \multirow[t]{2}{*}{ JAKFIN } & $(0.079)$ & $(0.051)$ & 0.100 \\
\hline & $(0.671)$ & $(0.411)$ & 0.803 \\
\hline \multirow[t]{2}{*}{ JAKINFR } & 0.077 & $(0.063)$ & 0.152 \\
\hline & 0.824 & $(0.643)$ & 1.566 \\
\hline \multirow[t]{2}{*}{ JAKMIND } & 0.092 & $(0.057)$ & $(0.120)$ \\
\hline & 0.932 & $(0.548)$ & $(1.155)$ \\
\hline \multirow[t]{2}{*}{ JAKMINE } & 0.161 & 0.100 & 0.049 \\
\hline & $2.839 * * *$ & $1.691 *$ & 0.837 \\
\hline \multirow[t]{2}{*}{ JAKPROP } & 0.072 & $(0.007)$ & $(0.021)$ \\
\hline & 0.902 & $(0.089)$ & $(0.252)$ \\
\hline \multirow[t]{2}{*}{ JAKTRAD } & $(0.182)$ & (0.133) & 0.003 \\
\hline & (1.533) & (1.072) & 0.026 \\
\hline CONST & 0.010 & 0.013 & 0.010 \\
\hline
\end{tabular}




\begin{tabular}{cccc}
\hline & $2.162^{* *}$ & $2.580^{* *}$ & $2.062^{* *}$ \\
\hline $\mathrm{R}^{2}$ & 0.120 & 0.033 & 0.046 \\
\hline Adj. $\mathrm{R}^{2}$ & 0.076 & $(0.015)$ & $(0.002)$ \\
\hline
\end{tabular}

*Significant at $10 \%$ level. **Significant at $5 \%$ level. $* * *$ Significant at $1 \%$ level.

Table 3. Regression results of the industry returns ability to predict JCI returns with control variable

\begin{tabular}{|c|c|c|c|}
\hline \multirow[b]{2}{*}{ Industry } & \multicolumn{3}{|c|}{ Dependent Variable: RM (ID) } \\
\hline & Month (t-1) & Month (t-2) & Month (t-3) \\
\hline \multirow{2}{*}{ JAKAGRI } & 0.041 & 0.036 & $(0.002)$ \\
\hline & 0.693 & 0.587 & $(0.031)$ \\
\hline \multirow[t]{2}{*}{ JAKBIND } & 0.114 & 0.144 & $(0.056)$ \\
\hline & 1.096 & 1.357 & $(0.513)$ \\
\hline \multirow[t]{2}{*}{ JAKCONS } & $(0.111)$ & 0.101 & 0.092 \\
\hline & $(1.042)$ & 0.930 & 0.822 \\
\hline \multirow[t]{2}{*}{ JAKFIN } & $(0.057)$ & 0.003 & 0.098 \\
\hline & $(0.466)$ & 0.024 & 0.759 \\
\hline \multirow[t]{2}{*}{ JAKINFR } & 0.079 & $(0.071)$ & 0.159 \\
\hline & 0.839 & $(0.741)$ & 1.606 \\
\hline \multirow[t]{2}{*}{ JAKMIND } & 0.085 & $(0.066)$ & $(0.124)$ \\
\hline & 0.859 & $(0.652)$ & $(1.187)$ \\
\hline \multirow[t]{2}{*}{ JAKMINE } & 0.159 & 0.094 & 0.048 \\
\hline & $2.804 * * *$ & 1.623 & 0.801 \\
\hline \multirow[t]{2}{*}{ JAKPROP } & 0.089 & 0.010 & $(0.015)$ \\
\hline & 1.099 & 0.124 & $(0.180)$ \\
\hline \multirow[t]{2}{*}{ JAKTRAD } & $(0.180)$ & $(0.128)$ & 0.001 \\
\hline & $(1.506)$ & $(1.050)$ & 0.005 \\
\hline \multirow[t]{2}{*}{ CONST } & 0.010 & 0.004 & 0.012 \\
\hline & 1.614 & 0.655 & $1.830 *$ \\
\hline $\mathrm{R}^{2}$ & 0.137 & 0.090 & 0.051 \\
\hline Adj. $\mathrm{R}^{2}$ & 0.078 & 0.027 & $(0.014)$ \\
\hline
\end{tabular}

\footnotetext{
*Significant at $10 \%$ level. **Significant at $5 \%$ level. ***Significant at $1 \%$ level.
} 
Industries' Ability to Predict the Market Return With and Without Control Variables After

\section{Excluding Years 2007-2009}

We investigate whether the Subprime Mortgage financial Crisis in the United States from 2007 to 2009 influenced the industries' ability to predict Jakarta Composite Index return. The regression results in Table 4 and Table 5 show that JAKMINE is able to predict the Jakarta Composite Index return and is significant at alpha 1\%. Both JAKMINE coefficients are positive and the same as JAKMINE coefficient in all periods (without excluding 2007 and 2009).

This table presents the results from industries return and control variable ability to predict JCI returns in $\mathrm{t}-1, \mathrm{t}-2$, and $\mathrm{t}-3$. The numbers besides the industry name represent the $\mathrm{t}$-stat for the previous industry return to predict the JCI return at month $\mathrm{t}$. The number under the $\mathrm{t}$-stat is the $\mathrm{p}$-value for the previous industry return's ability to predict the JCI return. CONST represent the alpha from the model. The numbers beside it represent the t-value and the numbers under the t-value are the p-value. In addition, each $\mathrm{R}^{2}$ and adjusted $\mathrm{R}^{2}$ of the model is displayed below the $\mathrm{p}$-value of the CONST. The sample period is 31 December 1999 - 31 December 2006 and 31 December 2009-30 September 2015.

Table 4. Regression results of the industry returns' ability to predict JCI returns after excluding year 2007-2009

\begin{tabular}{|c|c|c|c|}
\hline \multirow[b]{2}{*}{ Industry } & \multicolumn{3}{|c|}{ Dependent Variable: RM (ID) } \\
\hline & Month (t-1) & Month (t-2) & Month (t-3) \\
\hline \multirow[t]{2}{*}{ JAKAGRI } & 0.008 & $(0.004)$ & $(0.108)^{*}$ \\
\hline & 0.130 & $(0.069)$ & $(1.713)$ \\
\hline \multirow[t]{2}{*}{ JAKBIND } & 0.132 & 0.151 & 0.001 \\
\hline & 1.157 & 1.374 & 0.006 \\
\hline \multirow[t]{2}{*}{ JAKCONS } & $(0.107)$ & 0.077 & 0.059 \\
\hline & $(0.999)$ & 0.728 & 0.558 \\
\hline \multirow[t]{2}{*}{ JAKFIN } & $(0.090)$ & 0.081 & 0.183 \\
\hline & $(0.724)$ & 0.662 & 1.437 \\
\hline \multirow[t]{2}{*}{ JAKINFR } & 0.055 & $(0.080)$ & 0.147 \\
\hline & 0.594 & $(0.871)$ & 1.562 \\
\hline \multirow[t]{2}{*}{ JAKMIND } & 0.109 & $(0.078)$ & 0.042 \\
\hline & 0.948 & $(0.703)$ & 0.352 \\
\hline \multirow[t]{2}{*}{ JAKMINE } & 0.140 & 0.065 & 0.000 \\
\hline & $2.299 * *$ & 1.123 & 0.007 \\
\hline \multirow[t]{2}{*}{ JAKPROP } & 0.080 & $(0.047)$ & 0.001 \\
\hline & 0.959 & $(0.589)$ & 0.017 \\
\hline JAKTRAD & $(0.222)$ & $(0.213)$ & $(0.217)$ \\
\hline
\end{tabular}




\begin{tabular}{cccc}
\hline & $(1.759)^{*}$ & $(1.725)^{*}$ & $(1.694)^{*}$ \\
\hline CONST & 0.013 & 0.016 & 0.011 \\
\hline $\mathrm{R}^{2}$ & $2.556^{* *}$ & $3.327^{* * *}$ & $2.131^{* *}$ \\
\hline Adj. $\mathrm{R}^{2}$ & 0.096 & 0.045 & 0.090 \\
\hline
\end{tabular}

*Significant at $10 \%$ level. **Significant at $5 \%$ level. ***Significant at $1 \%$ level.

This table presents the results from industries return and control variable ability to predict JCI returns in $\mathrm{t}-1, \mathrm{t}-2$, and $\mathrm{t}-3$. The numbers besides the industry name represent the $\mathrm{t}$-stat for the previous industry return to predict the JCI return at month $\mathrm{t}$. The number under the $\mathrm{t}$-stat is the p-value for the previous industry return's ability to predict the JCI return. CONST represent the alpha from the model. The numbers beside it represent the $\mathrm{t}$-value and the numbers under the t-value are the p-value. In addition, each $\mathrm{R}^{2}$ and adjusted $\mathrm{R}^{2}$ of the model is displayed below the p-value of the CONST. The sample period is 31 December 1999 - 31 December 2006 and 31 December 2009-30 September 2015.

Table 5. Regression Results of The Industry Returns Ability to Predict JCI Returns with Control Variable after Excluding Year 2007-2009

\begin{tabular}{|c|c|c|c|}
\hline \multirow[b]{2}{*}{ Industry } & \multicolumn{3}{|c|}{ Dependent Variable: RM (ID) } \\
\hline & Month (t-1) & Month (t-2) & Month (t-3) \\
\hline \multirow[t]{2}{*}{ JAKAGRI } & 0.019 & 0.011 & $(0.107)$ \\
\hline & 0.294 & 0.171 & $(1.655)$ \\
\hline \multirow[t]{2}{*}{ JAKBIND } & 0.158 & 0.260 & 0.018 \\
\hline & 1.374 & $2.306 * *$ & 0.158 \\
\hline \multirow[t]{2}{*}{ JAKCONS } & $(0.107)$ & 0.103 & 0.053 \\
\hline & $(0.992)$ & 0.996 & 0.497 \\
\hline \multirow[t]{2}{*}{ JAKFIN } & $(0.091)$ & 0.097 & 0.197 \\
\hline & $(0.719)$ & 0.775 & 1.520 \\
\hline \multirow[t]{2}{*}{ JAKINFR } & 0.052 & $(0.092)$ & 0.135 \\
\hline & 0.558 & $(0.996)$ & 1.419 \\
\hline \multirow[t]{2}{*}{ JAKMIND } & 0.121 & $(0.075)$ & 0.051 \\
\hline & 1.048 & $(0.655)$ & 0.431 \\
\hline \multirow[t]{2}{*}{ JAKMINE } & 0.139 & 0.047 & 0.000 \\
\hline & $2.258 * *$ & 0.781 & 0.005 \\
\hline \multirow[t]{2}{*}{ JAKPROP } & 0.116 & $(0.047)$ & 0.020 \\
\hline & 1.312 & $(0.537)$ & 0.227 \\
\hline \multirow[t]{2}{*}{ JAKTRAD } & $(0.237)$ & $(0.237)$ & $(0.222)$ \\
\hline & $(1.863)^{*}$ & $(1.874)^{*}$ & $(1.711)^{*}$ \\
\hline CONST & 0.010 & 0.003 & 0.006 \\
\hline
\end{tabular}




\begin{tabular}{clll}
\hline & 1.511 & 0.474 & 1.006 \\
\hline $\mathrm{R}^{2}$ & 0.113 & 0.141 & 0.099 \\
\hline Adj. $\mathrm{R}^{2}$ & 0.036 & 0.067 & 0.021
\end{tabular}

*Significant at $10 \%$ level. $* *$ Significant at $5 \%$ level. $* * *$ Significant at $1 \%$ level.

There are three additional industry returns, i.e. JAKAGRI, JAKBIND, and JAKTRAD, that are able to predict Jakarta Composite Return. Their predictive ability is not robust. JAKAGRI return is only able to predict Jakarta Composite return prior three months and is significant at alpha $10 \%$. JAKBIND return in Table 4 without control variable is not significant but in Table $\mathbf{5}$ with control variable is significant prior two months. JAKTRAD return has a predictive ability to Jakarta Composite Index Return only after excluding Subprime Mortgage Crisis in one month prior, two months prior, and three months prior and is significant at alpha $10 \%$.

\section{Discussion}

Investors value investment based on historical information to create forward-looking estimates. Hence, a reliable source of historical information is needed. The reliable source of historical information is gained from the futures market that available today. As we all know, futures market facilitates price discovery in the future and offer instruments to transfer risk from commodities producer and commodities user. From the nine industries that we analyze, there are only two industries that have information advantage from futures market; the mining sector as represented by JAKMINE and the agriculture sector as represented by JAKAGRI. While both industries have the futures markets, the information gathered from the mining sector and the agriculture sector is different. The mining sector provides more information about economic activities that affect demand and supply for mining product such as iron, copper, and nickel. However, the agriculture sector have considerable information, such as weather and harvesting season, that not related to economic activities.

The mining sectors have direct and indirect effects to other industries. The mining sector's direct effect is experienced by specific industries that have their profitability changes in line with changes in commodities prices, such as oil industries which have direct effect to airlines industries. The mining sector's indirect effect is experienced by general industries through increased (decreased) cost of good sold, increased (decreased) product prices, increased (decreased) inflation rate, and central banks' action to tame (induce) inflation using interest rate policy.

Eventhough the mining sector's returns have the abilities to predict market returns (Jakarta Composite Index returns), the applicability is relatively limited. The coefficient of JAKMINE is 0.161\% for all periods (31 December 1999 to 30 September 2015), 0.159\% for all periods with control variables (inflation rate, change in deposits rate, and change in exchange rate), $0.140 \%$ for periods excluding 2007 through 2009, and 0.139\% for periods excluding 2007 through 2009 with control variables. It means that the highest expected market return from the model is $0.161 \%$ from $1.00 \%$ 
mining sector returns. The average transaction cost for stock in Indonesia is around $0.50 \%$ to $0.60 \%$, in which $0.25 \%$ for buying, $0.25 \%$ for selling stocks and an additional final income tax $0.1 \%$. Our findings show that eventhough the price is not right, there are still no free lunch.

\section{Research Limitation and Implication for Future Research}

Our statistical findings shows that model have relatively low explanation power as shown by r-square and adjusted r-square even though the industry stock performance variable is statistically significant. This model low explanation power pose a significant challenge to investor to apply the research model in managing their investment. Investor have tremendous difficulty to differentiate between real signal and market noise. Since this research model is built only on simple variable, i.e. industry stock performance, researcher have the opportunity to add future variables. We suggest several futures prices, such as futures prices of mining and agriculture product, futures prices of stock index prices, futures prices of bond yield and futures prices of exchange rates, as independent variable along with industry stock performance to increase model explanation power.

\section{CONCLUSIONS}

We find only one industry, i.e. JAKMINE - mining sector, that is able to predict the return of stock markets prior one month. Mining sector's predictive ability and significant level do not change whether we include all 16-year periods or when we exclude the crisis period from 2007 to 2009. The existence of lead-lag relations in Indonesia markets cannot be explained by standard finance explanation such as Indonesian market failure mechanisms, because lead-lag relations are not corrected within 16 years even though Indonesian markets already experience tremendous positive development. The existence of lead-lag relations in Indonesian market is consistent with the limited information-capacity processing because investors fail to gather and are slow to comprehend the information from mining sectors that are relatively complex and have small industry market capitalization that may not justify information processing cost.

The delicate nature of the signal from mining industry also adds support to limited information-processing capacity that can be seen in the relatively low model predictive ability or relatively low R-square. Our regression results show that mining sectors have a consistent significant level of $1 \%$ but with a relatively low R-square adjusted, i.e. $7.6 \%$ in all periods, $3.9 \%$ in periods that exclude the crisis period from 2007 to $2009,7.8 \%$ including control variable, and $3.6 \%$ in periods that exclude the crisis period from 2007 to 2009 and including control variables.

The mining sector's predictive ability stems from the existence of the futures markets that provide information about economic activities that affect demand and supply. The mining sector effect is experienced by general industries through increased (decreased) cost of good sold, increased 
(decreased) product prices, increased (decreased) inflation rate, and central banks' action to tame (induce) inflation using interest rate policy.

\section{REFERENCES}

Arjoon, V., Bougheas, S., \& Milner, C. 2016. Lead-Lag Relationships in an Embryonic Stock Market: Exploring The Role Of Institutional Ownership and Liquidity. Research in International Business and Finance. 38, Pg: 262-276.

Bodnaruk, A., \& Ostberg, P. 2009. Does Investor Recognition Predict Returns?. Journal of Financial Economics. 91. Pg: 208-226.

Chiao, C., Hung, K., \& Lee, C.F. 2004. The Price Adjustment and Lead-Lag Relations Between Stock Returns: Microstructure Evidence from The Taiwan Stock Market. Journal of Empirical Finance. 11. Pg: 709-731.

Drakos, A.A. 2016. Does The Relationship Between Small and Large Portfolios' Returns Confirm The Lead-Lag Effect? Evidence from The Athens Stock Exchange. Research in International Business and Finance. 36. Pg: 546-561.

Hacibedel, B. 2014. Does Investor Recognition Matter For Asset Pricing? Emerging Markets Review 21. Pg: $1-20$.

Hong, H., Torous, W., \& Valkanov, R. 2007. Do Industries Lead Stock Markets? Journal of Financial Economics. 83. Pg:367-396.

Judge, A., \& Reancharoen, T. 2014. An Empirical Examination of The Lead-Lag Relationship Between Spot and Futures Markets: Evidence from Thailand. Pacific-Basin Finance Journal. 29. Pg: 335-358.

Kleidon, A.W. 1986. Anomalies in Financial Economics: Blueprint for Change? Journal of Business 59. Pg: 469-499.

Merton, R.C. 1987. A Simple Model of Capital Market Equilibrium with Incomplete Information. Journal of Finance. 42. Pg: 483-510.

Oprean, C., \& Tanasescu, C. 2014. Effects of Behavioral Finance on Emerging Capital Markets. Procedia Economics and Finance. 15. Pg: 1710-1716.

Peng, L. 2005. Learning With Information Capacity Constraints. Journal of Financial and Quantitative Analysis. 40. Pg: 307-329.

Peng, L. \& Xiong, W. 2006. Investor Attention, Overconfidence and Category Learning. Journal of Financial Economics. 80. Pg: 563-602.

Poshakwale, S., \& Theobald, M. 2004. Market Capitalization, Cross-Correlations, The Lead-Lag Structure and Microstructure Effects in The Indian Stock Market. Journal of International Financial Markets, Institutions, and Money. 14. Pg: 385-400.

Sahi, S.K., \& Arora, A.P. 2012. Individual Investor Biases: A Segmentation Analysis. Qualitative Research in Financial Markets. 4. Pg: 6-25.

Statman, M.. 2014. Behavioral Finance: Finance with Normal People. Borsa Istanbul Review.14. Pg: $65-73$

Qiao, Z., Li, Y., \& Wong, W.K. 2008. Policy Change and Lead-Lag Relation Among China's Segmented Stock Markets. Journal of Multinational Financial Management. 18. Pg: 276-289. 